ENTREPRENEURSHIP AND SUSTAINABILITY ISSUES

ISSN 2345-0282 (online) http://jssidoi.org/jesi/

2020 Volume 8 Number 2 (December)

http://doi.org/10.9770/jesi.2020.8.2(27)

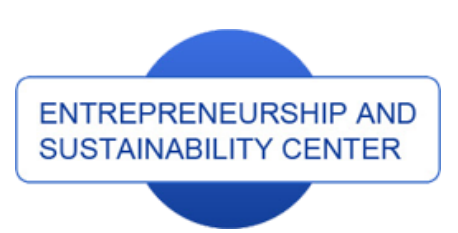

Publisher

http://jssidoi.org/esc/home

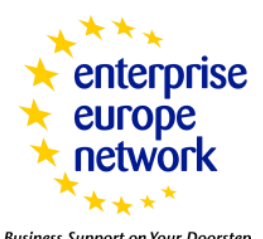

Business Support on Your Doorstep

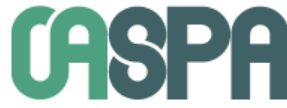

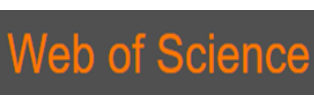

1) Clarivate

Analytics

\title{
DOES ENTREPRENEURIAL EDUCATION DRIVE STUDENTS' BEING ENTREPRENEURS? EVIDENCE FROM INDONESIA*
}

\author{
Djoko Dwi Kusumojanto ${ }^{1}$, Bagus Shandy Narmaditya ${ }^{2}$, Agus Wibowo ${ }^{3}$ \\ ${ }^{1,2}$ Faculty of Economics, Universitas Negeri Malang, Jalan Semarang 5 Malang, 65145, Indonesia \\ ${ }^{3}$ Faculty of Economics, Universitas Negeri Jakarta, Jalan Rawamangun Muka, Jakarta Timur, 13220, Indonesia \\ Email: ${ }^{1}$ djoko.dwi.fe@um.ac.id $;{ }^{2}$ bagus.shandy.fe@um.ac.id $;{ }^{3}$ agus-wibowo@unj.ac.id
}

Received 15 November 2019; accepted 27 August 2020; published 30 December 2020

\begin{abstract}
The aim of the present study was to investigate the role of entrepreneurship education and entrepreneurial intention by adding the current data in the context of Indonesia. This study also involves some variables that predicted affect students' entrepreneurial intentions, including entrepreneurial self-efficacy and entrepreneurial attitude. The study design applied in this research was a survey method with a quantitative approach to help understand the relationship between variables. This study used a convenience random sampling technique to collect the information of students in several state universities in Indonesia. The participants of this study were students in the second and third-year study who enrolled in the course of entrepreneurship and education and actively participated in programs of entrepreneurship. This investigation confirms four hypotheses and rejects the two hypotheses proposed. In more detail, entrepreneurship education successfully influences entrepreneurial self-efficacy and students' attitudes toward entrepreneurship. However, it failed in promoting students' intention of being an entrepreneur. On the other hand, entrepreneurial self-efficacy has an impact on entrepreneurial attitude, while entrepreneurial attitude does not influence on students' entrepreneurial intentions. Lastly, from this study, it showed that entrepreneurial attitude insufficient in mediating entrepreneurship education and intention being entrepreneurs.
\end{abstract}

Keywords: entrepreneurial education; entrepreneurial intention; entrepreneurial attitude; self-efficacy

Reference to this paper should be made as follows: Kusumojanto, DD., Narmaditya, BS., Wibowo, A. 2020. Does Entrepreneurial Education Drive Students' Being Entrepreneurs? Evidence from Indonesia. Entrepreneurship and Sustainability Issues, 8(2), 454-466. http://doi.org/10.9770/jesi.2020.8.2(27)

JEL Classifications: I25, L26

\footnotetext{
* This research was supported by Faculty of Economics, Universitas Negeri Malang, Indonesia
} 


\section{ENTREPRENEURSHIP AND SUSTAINABILITY ISSUES}

ISSN 2345-0282 (online) http://jssidoi.org/jesi/

2020 Volume 8 Number 2 (December)

http://doi.org/10.9770/jesi.2020.8.2(27)

Make your research more visible, join the Twitter account of ENTREPRENEURSHIP AND SUSTAINABILITY ISSUES: @Entrepr69728810

\section{Introduction}

An important question continually confronted by governments in both developed and emerging countries is how to incline the number of entrepreneurs. The fundamental rationale is that small and business provides new job opportunities that can contribute for economic development, economic growth and community wellbeing (Turkina \& Thai, 2013; Hoz-Rosales et al., 2019; Tung et al., 2020). One way to escalate entrepreneurs is through entrepreneurial education program to ensure individual have adequate knowledge needed for preparing a business. Scholar have documented the role of entrepreneurship education as a driving factor to insight into entrepreneurship from the formal education side (Maresch et al., 2016; Gerba, 2015; Bae et al., 2014).

As was pointed the essential role of entrepreneurial education, Kourilsky and Walstad (1998) suggested to enhance the entrepreneurship education from elementary school to tertiary education, particularly on developing countries. Likewise, Indonesian government also promotes an entrepreneurship program for students, which intended to boost the number of entrepreneurs (Saptono et al., 2018; Purwana et al., 2019). The policy to increase the number of entrepreneurs in Indonesia is forecasted in two primary functions; accelerating the presence of prosperity and reducing the number of unemployed young people (Patricia \& Silangen, 2016; Utami, 2017).

In the context of Indonesia, the unemployment rate in Indonesia by approximately 5.28 per cent is dominated by college graduates (Statistics Indonesia, 2019). Dealing with this issue, universities in Indonesia need to revitalize the implementation of entrepreneurship education. Furthermore, universities require a comprehensive model of entrepreneur education, covering targets, learners, content, methods, and evaluation by placing targets as a central component (Muwarni, 2016; Gautam \& Singh, 2015). The lack of entrepreneurial intentions among college graduates needs to be concerned by the government. Entrepreneurial intentions can be seen from the willingness to work hard and diligently to achieve business progress, the willingness to bear the various risks associated with doing business in doing it, willing to take new paths and ways, willingness to live frugally and to learn from experience.

Accordingly, entrepreneurial intention among university students can be explained by several factors, including norms, self-efficacy, environment, education, and attitude (Maresch, 2016). Having already witnessed a review of this field, Uddin and Bose (2012) pointed out that the tendency to take risks, the need for achievement, education and the environment to start a business, job security is essential in determining student intentions. In acquaintance with entrepreneurship education, Zhao et al. (2005) found a positive correlation toward entrepreneurial intentions, particularly when this relationship works according to favourable perceptions of entrepreneurship. Wu and $\mathrm{Wu}$ (2008) noted educational factors that influenced attitudes toward and perceived behavioural control positively influenced student entrepreneurial intentions. However, from the study, it found that subjective norms did not significantly influence entrepreneurial intentions.

Based on the theory of planned behaviour (TPB), attitudes and perceived behavioural have a correlation, while subjective norms have a lower significance. A prior study by Zhang et al. (2014) demonstrated that education has no influence on intention, whilst knowledge also has no impact on individual ability. Samydevan et al. (2015) added that psychological, educational and cultural characteristics influence entrepreneurial intentions among students in Malaysia. In addition, Ferreira et al. (2017) stated that self-efficacy has a relationship with intention of being entrepreneurs. Meanwhile, Ogunleye and Osagu (2014) revealed that self-efficacy, achievement motivation, age and gender did not significantly predict entrepreneurial orientation. Gedik et al. (2015) indicated that three attitude variables towards entrepreneurship, role models, and entrepreneurship education courses contributed to 


\section{ENTREPRENEURSHIP AND SUSTAINABILITY ISSUES}

ISSN 2345-0282 (online) http://jssidoi.org/jesi/

2020 Volume 8 Number 2 (December)

http://doi.org/10.9770/jesi.2020.8.2(27)

Make your research more visible, join the Twitter account of ENTREPRENEURSHIP AND SUSTAINABILITY ISSUES: @Entrepr69728810

student motivation in entrepreneurship. Furthermore, Tong et al. (2011) found students would choose to become entrepreneurs as long as there was a need for achievement, family business background, and subjective influence.

This study contributes of the present study are three folds. First, it contributes to the existing litrerature on factors affecting students being entrepreneurs by enhancing variables self-efficacy and entrepreneurial attitude that is missing in the prior works. Second, the inevitable studies of entrepreneurship education and entrepreneurial intention have largely investigated across the world. For instance, Tung et al. (2020) in Vietnam and Philippines, (Maresch, 2016) in Ethiopia, Uddin and Bose (2012) in Bangladesh, while this study has been conducted in Indonesia. The focus on Indonesia is unique due to the fact that the lack of entrepreneurs although it has great market and resources (Eryanto, 2019; Saptono et al., 2019). Additionally, this study presents an insight into the mediating role of self-efficacy and entrepreneurial attitude in explaining students intention being entrepreneurs.

\section{Theoretical background}

\subsection{Entrepreneurship Education}

Fayolle and Gailly (2015) revealed that entrepreneurship education emphasizes on preparing business plans, how to get financing, business development processes, and small business management. The education provides knowledge about the principles of entrepreneurship and technical skills regarding business management. Wang (2004) found that the inadequate level of students' perception and knowledge on entrepreneurship before taking entrepreneurial education. Lee and Wong (2003) asserted that entrepreneurship education in tertiary institutions has a direct relationship in shaping the attitude of students in taking risks for the establishment of new businesses. For these reasons, entrepreneurship education must be designed in such a way as to have an impact on encouraging students' intention to become entrepreneurs.

In the literature, several prior studies have investigated the entrepreneurial education and intention being entrepreneurs in many countries. For instance, (Maresch, 2016) showed a positive correlation between those variables in Ethiopia. Indeed, in Bangladesh, Uddin and Bose (2012) found that entrepreneurship education influences students' entrepreneurial intention. The study of entrepreneurship education was also conducted in other countries in Vietnam and the Philippines (Tung et al., 2020). Also, Zhao et al. (2005) pointed out relevant implications that entrepreneurship education is positively related to entrepreneurial intentions, primarily when this relationship works according to favourable perceptions of entrepreneurship.

The entrepreneurial intention is measured by several indicators, including involvement in entrepreneurship programs on campus, starting self-employment after graduation, working with excellent partners after graduation and starting entrepreneurship if there is funding support (Autio et al., 2001; Kolvereid \& Isaksen, 2006; Zhao et al., 2005). Furthermore, Turker (2009) proposed the indicator to measure intention, such as choosing the path of business rather than working for someone else, choosing a career as an entrepreneur, and planning to start a business. Meanwhile, Shapero and Sokol (1982) expressed that entrepreneurial intentions depend on three elements: a sense of desire, a tendency to act, and a sense of worthiness. A sense of desire is defined as the personal attraction of starting a business. Eligibility is considered understood as a belief in the ability to start a business, and a tendency to act refers to one's disposition to act decisively when faced with an opportunity.

In addition, a correlation between entrepreneurship education and self-efficacy have confirmed by Saptono and Wibowo (2018); Wibowo et al. (2018). Indeed, Keat et al. (2011) mentioned that the primary goal of entrepreneurship education is to change the views, behaviours, attitudes and intentions of students to understand entrepreneurship, have an entrepreneurial mindset, and later become successful entrepreneurs building businesses. 


\section{ENTREPRENEURSHIP AND SUSTAINABILITY ISSUES}

ISSN 2345-0282 (online) http://jssidoi.org/jesi/

2020 Volume 8 Number 2 (December)

http://doi.org/10.9770/jesi.2020.8.2(27)

Make your research more visible, join the Twitter account of ENTREPRENEURSHIP AND SUSTAINABILITY ISSUES: @Entrepr69728810

Similarly, Sizong et al. (2008) also argue that entrepreneurship education significantly influences a person's attitude to be an entrepreneur. Besides, the influence of entrepreneurship education and entrepreneurial attitude was documented by Ambad and Damit (2016); Lüthje and Franke (2003); Ozaralli and Rivenburgh (2016); Turker and Selcuk (2009); Yang (2013), which indicates that the entrepreneurial attitude has an impact on intention being entrepreneur.

H1: Entrepreneurship education influences students' entrepreneurial self-efficacy

H2: Entrepreneurship education influences students' entrepreneurial attitude

H3: Entrepreneurship education influences students' entrepreneurial intention

\subsection{Self-efficacy}

In addition to entrepreneurial education, the formation of student entrepreneurial intentions is self-efficacy. According to King (2012), self-efficacy is the belief that someone can master a situation and produce various positive results. Self-efficacy helps people in various unsatisfactory situations and encourages them to believe that they can succeed. Self-efficacy plays a role in decision making, thought processes, and courage in taking risks. Every individual who has high entrepreneurial intentions will be able to stand alone, dare to make decisions, and implement goals to be achieved at their discretion. This shows that the higher the self-efficacy will lead to greater entrepreneurial intention (Ogunleye \& Osagu, 2014). Several prior studies believed that self-efficacy will lead to the intention of being entrepreneurs (Ayodele, 2013; Guzmán-Alfonso \& Guzmán-Cuevas, 2012), while the results of some researchers showed an insignificant impact between self-efficacy and entrepreneurial intention (Ferreira et al., 2017; Ogunleye \& Osagu, 2014).

H4: Entrepreneurial self-efficacy influences students' entrepreneurial attitude

\subsection{The mediating Role of Entrepreneurial Attitude}

Another significant aspect of intention being entrepreneurs is attitude. Keat et al. (2011) pointed out that students' entrepreneurial intention is affected by entrepreneurship education. Through the learning process on entrepreneurship, it will lead to changes in behaviours and interests of students in order to understand entrepreneurship and have an entrepreneurial mindset and later become entrepreneurs. Similarly, Wu and Wu (2008) confirmed that entrepreneurship education significantly influences an individual's attitude to be an entrepreneur.

Rosmiati et al. (2015) noted that attitude is an emotional readiness in some action on something appropriate or as something that is learned and how individuals react to situations and determine what is sought in life. The entrepreneurial attitude is the tendency to react adequately in responding to the risks that will be faced in business. Moreover, Gedik et al. (2015) viewed individuals who show a positive attitude towards entrepreneurship, are more likely to act as an entrepreneur and believe that entrepreneurship is not just a method of survival but a way to achieve self-actualization. Based on the previous theoretical studies and previous research, this study tests the following hypotheses.

H5: Entrepreneurial attitude influences students' entrepreneurial intention;

H6: Entrepreneurial attitude mediates the impact of entrepreneurship education on students' entrepreneurial intention. 
ENTREPRENEURSHIP AND SUSTAINABILITY ISSUES

ISSN 2345-0282 (online) http://jssidoi.org/jesi/

2020 Volume 8 Number 2 (December)

http://doi.org/10.9770/jesi.2020.8.2(27)

Make your research more visible, join the Twitter account of ENTREPRENEURSHIP AND SUSTAINABILITY ISSUES: @Entrepr69728810

\section{Research objective and methodology}

\subsection{Empirical Study Design}

The study design applied in this research was a survey method with a quantitative approach. The benefit of adopting this approach gains a detailed understanding of how entrepreneurial education, entrepreneurial attitude, and self-efficacy influence students' intention of being entrepreneurs (see figure 1). This study used a convenience random sampling technique to collect the information of students in several state universities in Indonesia, including Universitas Negeri Malang, Universitas Negeri Jakarta and Universitas Negeri Semarang. The fundamental reason is that those universities represent each region, Universitas Negeri Malang (East Java), Universitas Negeri Semarang (Central Java), and Universitas Negeri Jakarta (West Java). This study was conducted for about two months, from January to February. The participants of this study were students in the second and third-year study who enrolled in the course of entrepreneurship and education and actively participated in programs of entrepreneurship. The leading researcher distributed 300 questionnaires, and 290 were returned, a response rate of 96.7 per cent. The majority respondent of this study was female by approximately 65 per cent, which reflected a higher proportion than male.

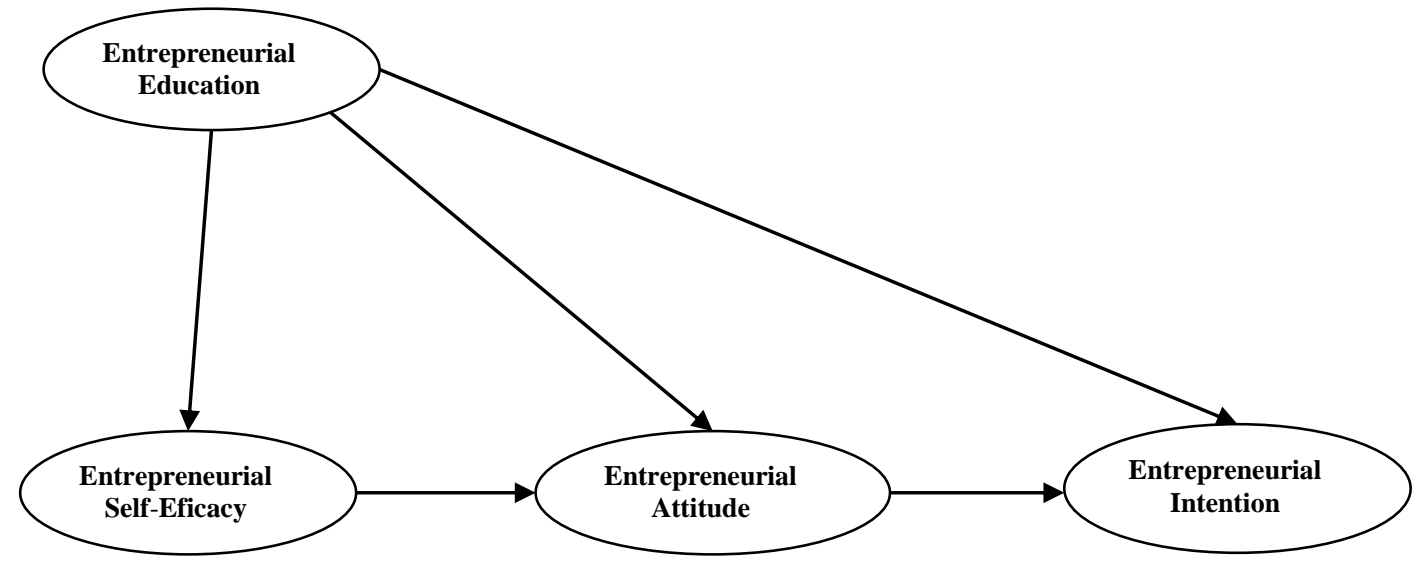

Figure 1. Theoretical Framework

Source: authors (2020)

\subsection{Measurement and Data Analysis}

The survey questionnaires used to collect information about entrepreneurial education (EE) were adapted from Souitaris et al. (2007), and Denanyoh et al. (2015). Besides, the entrepreneurial intention (EI) was measured by eight items instruments adapting from Zhao et al. (2005); Kolvereid and Isaksen (2006); Linan \& Chen (2009). Meanwhile, to measure entrepreneurial self-efficacy (ES), we adapted 14 items developed by Ferreira et al. (2017); Zhao et al. (2005). Lastly, entrepreneurial attitude (AE) was measured by nine items of instruments developing by Yang (2013); Linan and Chen (2009). This study used a 5-point Likert scale in an attempt to gauge responses comprehensively.

This study engaged two stages of data analysis: exploratory factor analysis and confirmatory factor analysis. The initial test is aimed at validating, exploration dimensions, and maintaining strong indicators by using SPSS version 18 (Allen \& Bennett, 2010). A construct is said to be reliable if it has an alpha Cronbach $(\alpha)$ score equal to or higher than 0.6 (Hair et al., 2006). The next test was the confirmatory factor analysis (CFA) AMOS version 18. 
ENTREPRENEURSHIP AND SUSTAINABILITY ISSUES

ISSN 2345-0282 (online) http://jssidoi.org/jesi/ 2020 Volume 8 Number 2 (December)

http://doi.org/10.9770/jesi.2020.8.2(27)

Make your research more visible, join the Twitter account of ENTREPRENEURSHIP AND SUSTAINABILITY ISSUES: @Entrepr69728810

The model tested needs to satisfy several criteria and a cut-off value, including p-value (probability) $>0.5$ to obtain a fit model (Schermelleh-Engel et al., 2003). Furthermore, CMIN / DF values <2 (Tabachnick \& Fidell, 2007), CFI $>0.95$ (Hu \& Bentler, 1999), and RMSEA $\leq 0.05$ (Hu \& Bentler, 1999).

\section{Results and Discussion}

\subsection{Resuts}

Based on the initial test using exploratory factor analysis, it is known that from a total of 43 factors, including entrepreneurship education (12), entrepreneurial intention (8), entrepreneurial self-efficacy (14), and entrepreneurial attitude (9). Each variable has a loading factor of 0.621 to 0.917 , and a Cronbach's alpha between 0.678 to 0.906 . Moreover, based on SEM calculation results to check the theoretical framework and fitted models, a probability score of 0.073 is obtained, a CMIN / DF score of 1.324, a CFI score of 0.971, an FMIN score of 0.202 and an RMSEA score of 0.034 .

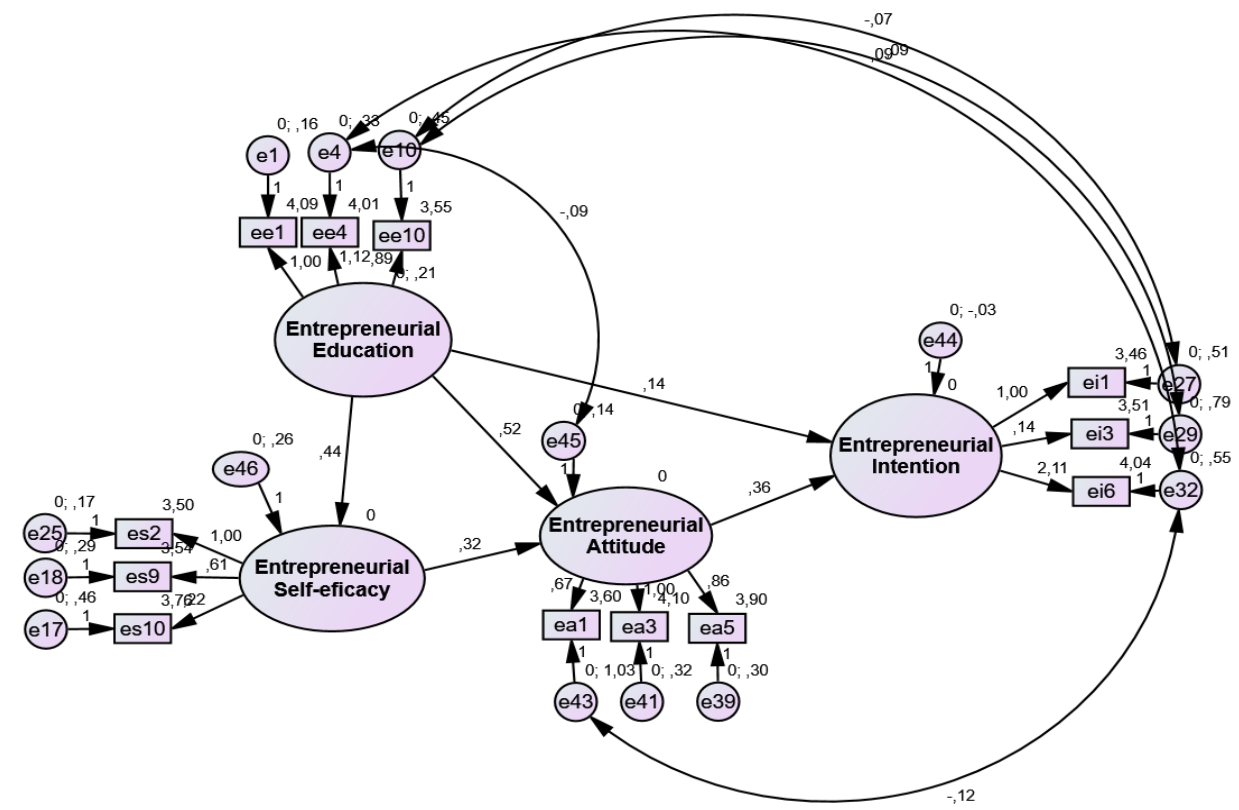

Figure 2. Results of the Structural Equation Research Model

Source: authors (2020)

Table 1. Result Summary of Hypotheses testing

\begin{tabular}{|c|c|c|c|c|c|c|c|c|}
\hline & & & & Estimate & S.E. & C.R. & $\boldsymbol{P}$ & Result \\
\hline $\mathrm{H}_{1}$ & $\mathrm{EE}$ & $\rightarrow$ & ES & 0.438 & 0.106 & 4.131 & $* * *$ & Significant \\
\hline $\mathrm{H}_{2}$ & $\mathrm{EE}$ & $\rightarrow$ & EA & 0.520 & 0.128 & 4.054 & $* * *$ & Significant \\
\hline $\mathrm{H}_{3}$ & $\mathrm{EE}$ & $\rightarrow$ & EI & 0.144 & 0.080 & 1.795 & 0.073 & Insignificant \\
\hline $\mathrm{H}_{4}$ & ES & $\rightarrow$ & EA & 0.322 & 0.105 & 3.067 & 0.002 & Significant \\
\hline $\mathrm{H}_{5}$ & EA & $\rightarrow$ & EI & 0.358 & 0.102 & 3.515 & $* * *$ & Significant \\
\hline $\mathrm{H}_{6}$ & \multicolumn{7}{|c|}{$\mathrm{EE} \rightarrow \mathrm{EA} \rightarrow \mathrm{EI}=\mathrm{b}$ score 1.601} & Insignificant \\
\hline
\end{tabular}

Source: authors (2020)

Note: $\mathrm{EE}=$ entrepreneurial education; $\mathrm{ES}=$ entrepreneurial self-efficacy; $\mathrm{EA}=$ entrepreneurial attitude; EI = entrepreneurial intention 


\section{ENTREPRENEURSHIP AND SUSTAINABILITY ISSUES}

ISSN 2345-0282 (online) http://jssidoi.org/jesi/

2020 Volume 8 Number 2 (December)

http://doi.org/10.9770/jesi.2020.8.2(27)

Make your research more visible, join the Twitter account of ENTREPRENEURSHIP AND SUSTAINABILITY ISSUES: @Entrepr69728810

Table 1 informs the summary of the hypothesis testing between variables. In general, the variables tested were satisfied with the model. In more detail, $\mathrm{H}_{1}, \mathrm{H}_{2}, \mathrm{H}_{4}$, and $\mathrm{H}_{5}$ were significant, with the C.R score is 4.131, 4.054, 3.067, and 3.515, respectively. These results, according to Hair et al. (2006), the C.R value of each of these hypotheses is significant because of \pm 1.96 . In contrast, $\mathrm{H}_{3}$ and $\mathrm{H}_{6}$ were not significant because of the C.R value of 1.795 and 1.601 , respectively.

\subsection{Discussion}

Based on the previous analysis, this study has successfully addressed the six hypotheses proposed. The result of this study is relevant to the previous study by Fayolle and Gailly (2015); Laviolette (2012); Sánchez (2013); Von Graevenitz (2010). Indeed, the finding of this study agreed with previous papers in Indonesia context by Purwana and Suhud (2017); Saptono and Wibowo et al. (2018). The discovery of the study confirms the importance of entrepreneurship education. In order to improve students' self-efficacy, entrepreneurship education does not only cover at the theory of entrepreneurship, but also the practice of how to become an entrepreneur. The universities should hold various seminars related to entrepreneurship, by presenting practitioners and alumni who are already successful entrepreneurs. Their best practice will inspire students, as well as foster their self-efficacy so that the entrepreneurial intention is more definite. The practice of entrepreneurship should cooperate with various government and private agencies, so students increasingly understand how to build business relationships/business networks, market products, and find additional capital for businesses.

The second set question aims to understand the relationship between entrepreneurship education and entrepreneurial attitude. This result corroborates the findings of a great deal of the previous work by the Asia region (Bae et al., 2014; Ozaralli \& Rivenburgh: 2016; Peng, Lu, \& Kang, 2012). Also, this finding supports several prior studies, which conducted in Indonesia by Saptono and Wibowo (2018); Wibowo et al. (2018). Indeed, Keat et al. (2011) mentioned that the primary goal of entrepreneurship education is to change the views, behaviours, attitudes and intentions of students to understand entrepreneurship, have an entrepreneurial mindset, and later become successful entrepreneurs building businesses. Similarly, Sizong et al. (2008) also argue that entrepreneurship education significantly influences a person's attitude to be an entrepreneur. The majority of studies found that entrepreneurship education plays an essential role in building student entrepreneurial attitudes. Lee and Wong (2004) in their study findings reinforce Ajzen's $(1991,2002)$ with the theory of planned behaviour (TPB). Keat et al. (2011) asserted that the primary goal of entrepreneurship education is to change the views, behaviour and interests of students. Hence, they understand about entrepreneurship, and have an entrepreneurial mindset and later become successful entrepreneurs who build new businesses so they can open new job opportunities. Additionally, student attitudes can be improved by entrepreneurship education, increasing the practice of entrepreneurship (George \& Bock, 2011; Souitaris et al., 2007). Through practice, entrepreneurship education enables students to have a lot of knowledge and practice it directly. Such an educational model will further strengthen the entrepreneurial attitudes of students while increasing their entrepreneurial intentions (Wu \& $\mathrm{Wu}, 2008)$.

However, another finding of this study demonstrated that entrepreneurial education does not impact students' entrepreneurial intentions. This finding is in opposite with antecedent studies in Europe and Asia countries (Maresch et al., 2016; Barba-Sánchez \& Atienza-Sahuquillo, 2018; Fayolle, 2015; Sánchez, 2011; Souitaris et al., 2007; Zhang et al., 2014) which found that entrepreneurship education influences entrepreneurial intention. However, our findings are relevant to the data from Statistics Indonesia (2019), which stated that the number of unemployed in Indonesia is 5.28 per cent, with the highest number contributed by universities. It implies that entrepreneurship education from elementary to tertiary levels has not been effective in growing student 


\section{ENTREPRENEURSHIP AND SUSTAINABILITY ISSUES}

ISSN 2345-0282 (online) http://jssidoi.org/jesi/

2020 Volume 8 Number 2 (December)

http://doi.org/10.9770/jesi.2020.8.2(27)

Make your research more visible, join the Twitter account of ENTREPRENEURSHIP AND SUSTAINABILITY ISSUES: @Entrepr69728810

entrepreneurial intentions. Therefore, universities in Indonesia need to revitalize the implementation of entrepreneurship education. Moreover, the university's efforts to grow entrepreneurship require a comprehensive entrepreneur education model that includes targets, learners, content, methods and evaluation by placing targets as a central component (Muwarni, 2016).

Entrepreneurial self-efficacy has an impact on students' entrepreneurial attitude. This study supports evidence from previous observations by Ayodele (2013); Guzmán-Alfonso and Guzmán-Cuevas (2012); Samydevan (2015); Ferreira et al. (2017), which states that the TPB component influences entrepreneurial attitude and entrepreneurial intention, where one component of TPB is self-efficacy. However, this outcome is contrary to that of Ogunleye and Osagu (2014), that remarked self-efficacy does not significantly influence entrepreneurial attitude and entrepreneurial intention. Entrepreneurial self-efficacy contributes to entrepreneurial attitudes. Our findings are relevant to Bandura (1989), who mentioned that self-efficacy can successfully carry out the desired behaviour, has a robust link with entrepreneurial attitudes and intentions. This finding is reinforced by and Conner et al. (2011) which states that self-efficacy correlates very strongly to one's intentions and attitudes.

The fifth question in this study sought to determine the influence of entrepreneurial attitude toward students' entrepreneurial intention. This result is in accord with recent studies by Ambad and Damit (2016); Lüthje and Franke (2003); Ozaralli and Rivenburgh (2016); Turker and Selcuk (2009); Yang (2013) indicating that the entrepreneurial attitude has an impact on intention being entrepreneur. Indeed, this finding agrees with prior studies by Utami (2017), which stated that entrepreneurial intention is influenced by entrepreneurial attitude, subjective norms, and intentional behaviour control. Gallyn and Waspada (2012) stated that the variable attitude of entrepreneurial students has a positive influence on entrepreneurial intentions. Indeed, Keat et al. (2011), entrepreneurship education became a compelling scenario in shaping entrepreneurial attitudes. Because, the main objective of entrepreneurship education is to change the views, attitudes and interests of students to understand about entrepreneurship, and have an entrepreneurial mindset and later become successful entrepreneurs who build new businesses so they can open new job opportunities. This is relevant to the findings of Sizong et al. (2008) that entrepreneurship education significantly influences a person's attitude to be an entrepreneur, while entrepreneurial attitudes significantly influence entrepreneurial intentions.

The last question in this research was intended to understand the role of entrepreneurial attitude. For this finding, entrepreneurial attitude failed in mediating the impact of entrepreneurial education and students' entrepreneurial intention. This finding is contrary to previous studies which have suggested Lüthje and Franke (2003); Ozaralli and Rivenburgh (2016); Von Graevenitz et al. (2010); Yang (2013) and Zhang et al. (2014) that entrepreneurial attitude as a component of TPB mediates the effect of entrepreneurial education on entrepreneurial intention. Therefore, it can be stated that the implementation of entrepreneurial education in Indonesia has not been effective in influencing both directly and indirectly on entrepreneurial intention. This indicates that entrepreneurship education in a number of universities in Indonesia has not been effective in shaping attitudes and intentions. The data from Statistics Indonesia (2019) states that the majority of tertiary education graduates in Indonesia are afraid to take risks and tend to choose to become a private employee, civil servant, or state-owned company employee as their career choice. These conditions indicate that the intention to become an entrepreneur after graduating into a bachelor becomes a low-level entrepreneur. A practical step in overcoming this phenomenon is to revitalize entrepreneurial education to be more comprehensive: covering targets, learners, content, methods and evaluations by placing targets as central components. Entrepreneurship education must be an entrepreneurial education, where principles and methodologies are applied towards the formation of life skills for students through an integrated curriculum developed at the university. This is important considering that 


\section{ENTREPRENEURSHIP AND SUSTAINABILITY ISSUES}

ISSN 2345-0282 (online) http://jssidoi.org/jesi/

2020 Volume 8 Number 2 (December)

http://doi.org/10.9770/jesi.2020.8.2(27)

Make your research more visible, join the Twitter account of ENTREPRENEURSHIP AND SUSTAINABILITY ISSUES: @Entrepr69728810

entrepreneurship education obtained during college will be the essential capital for students to start and build a new business.

\section{Conclusions}

The present study aims to examine the relationship between variables, including entrepreneurial education, selfefficacy, entrepreneurial attitude, and intention being entrepreneurs. This investigation confirms four hypotheses and rejects the two hypotheses proposed. In more detail, entrepreneurship education successfully influences entrepreneurial self-efficacy and students' attitudes toward entrepreneurship. However, it failed in promoting students' intention to being an entrepreneur. On the other hand, entrepreneurial self-efficacy has an impact on entrepreneurial attitude, while entrepreneurial attitude does not influence students' entrepreneurial intentions. Lastly, from this study, it showed that entrepreneurial attitude insufficient in mediating entrepreneurship education and intention being entrepreneurs.

Taken together, these results suggest that universities need to design and implement various activities to encourage lecturers to apply a variety of creative and innovative learning methods and models, providing facilities and infrastructure to support entrepreneurial activities to create an entrepreneurial attitude and entrepreneurial intention. Furthermore, entrepreneurship education must also be revitalized, especially the curriculum, strategies, methods, facilities, and infrastructure, as well as the learning environment. This is so that entrepreneurship education can effectively influence student entrepreneurial intention. The most important limitation lies in the fact that the data was collected in three state universities in Indonesia, which the findings cannot be generalized to represent real conditions in all universities. The suggestion for further studies, it can develop a study with a broader area, for example, non-educational public universities with more complex data obtained and can be used as a basis for stakeholders in implementing policies related to increasing the number of entrepreneurs in Indonesia.

\section{References}

Ajzen, I. (1991). The theory of planned behavior. Organizational behavior and human decision processes, 50(2), $179-211$. https://doi.org/10.1016/0749-5978(91)90020-T

Allen, P., Bennett, K., \& King, J. (2010). PASW statistics by SPSS: A practical guide, version 18.0. National Library of Australia.

Ambad, S. N. A., \& Damit, D. H. D. A. (2016). Determinants of entrepreneurial intention among undergraduate students in Malaysia. Procedia Economics and Finance, 37, 108-114. https://doi.org/10.1016/S2212-5671(16)30100-9

Autio, E., H. Keeley, R., Klofsten, M., GC Parker, G., \& Hay, M. (2001). Entrepreneurial intention among students in Scandinavia and in the USA. Enterprise and Innovation Management Studies, 2(2), 145-160. https://doi.org/10.1080/14632440110094632

Ayodele, K. O. (2013). Demographics, entrepreneurial self-efficacy and locus of control as determinants of adolescents' entrepreneurial intention in Ogun state, Nigeria. European Journal of Business and Social Sciences, 1(12), 59-67. Retrieved April 14, 2020, from https://publication.babcock.edu.ng/asset/docs/publications/EDFO/9454/3281.pdf

Bandura, A. (1989). Human agency in social cognitive theory. American psychologist, 44(9), 1175. https://doi.org/10.1037/0003$\underline{066 X .44 .9 .1175}$

Bae, T. J., Qian, S., Miao, C., \& Fiet, J. O. (2014). The relationship between entrepreneurship education and entrepreneurial intentions: A meta-analytic review. Entrepreneurship Theory and Practice, 38(2), 217-254. https://doi.org/10.1111/etap.12095 


\section{ENTREPRENEURSHIP AND SUSTAINABILITY ISSUES}

ISSN 2345-0282 (online) http://jssidoi.org/jesi/

2020 Volume 8 Number 2 (December)

http://doi.org/10.9770/jesi.2020.8.2(27)

Make your research more visible, join the Twitter account of ENTREPRENEURSHIP AND SUSTAINABILITY ISSUES: @Entrepr69728810

Barba-Sánchez, V., \& Atienza-Sahuquillo, C. (2018). Entrepreneurial intention among engineering students: The role of entrepreneurship education. European Research on Management and Business Economics, 24(1), 53-61. https://doi.org/10.1016/j.iedeen.2017.04.001

Conner, M., Rhodes, R. E., Morris, B., McEachan, R., \& Lawton, R. (2011). Changing exercise through targeting affective or cognitive attitudes. Psychology and Health, 26(2), 133-149. https://doi.org/10.1080/08870446.2011.531570

Denanyoh, R., Adjei, K., \& Nyemekye, G. E. (2015). Factors that impact on entrepreneurial intention of tertiary students in Ghana. International Journal of Business and Social Research, 5(3), 19-29. Retrieved April 14, 2020, from https://www.thejournalofbusiness.org/index.php/site/article/view/693/506

Eryanto, H., Swaramarinda, D. R., \& Nurmalasari, D. (2019). Effectiveness of entrepreneurship practice program: Using cipp program evaluation. Journal of Entrepreneurship Education, 22(1), 1-10.

Fayolle, A., \& Gailly, B. (2015). The impact of entrepreneurship education on entrepreneurial attitudes and intention: Hysteresis and persistence. Journal of Small Business Management, 53(1), 75-93. https://doi.org/10.1111/jsbm.12065

Ferreira, A. D. S. M., Loiola, E., \& Gondim, S. M. G. (2017). Individual and contextual predictors of entrepreneurial intention among undergraduates: a literature review. Cadernos Ebape. $\mathrm{Br}, 15(2)$. https://doi.org/10.1590/1679-395159595

Fishbein., \& Ajzen. (1975). Belief, Attitude, Intentions and Behavior: an introduction to theory and research. California: Addison-Wesley Publishing Company, Inc. Retrieved April 14, 2020, from https://people.umass.edu/aizen/f\&a1975.html

Gallyn, D. M., \& Waspada, I. (2012). Faktor-Faktor yang Mempengaruhi Minat Berwirausaha Mahasiswa Universitas Pendidikan Indonesia. Jurnal Pendidikan Islami, 1(2), 1-14.

Gautam, M. K., \& Singh, S. K. (2015). Entrepreneurship education: concept, characteristics and implications for teacher education. An International Journal of Education, 5(1), 21-35. Retrieved April 14, 2020, from www.researchgate.net

Gedik, Ş., Miman, M., \& Kesici, M. S. (2015). Characteristics and attitudes of entrepreneurs towards entrepreneurship. Procedia-Social and Behavioral Sciences, 195, 1087-1096. https://doi.org/10.1016/j.sbspro.2015.06.153

Gerba, D. T. (2012). Impact of entrepreneurship education on entrepreneurial intentions of business and engineering students in Ethiopia. Journal of Economic and Management Studies, 3(2), 258-277. https://doi.org/10.1108/20400701211265036

Guzmán-Alfonso, C., \& Guzmán-Cuevas, J. (2012). Entrepreneurial intention models as applied to Latin America. Journal of Organizational Change Management, 25(5), 721-735. https://doi.org/10.1108/09534811211254608

Hair, J. F., Black, W. C., Babin, B. J., Anderson, R. E., \& Tatham, R. L. (2006). Multivariate data analysis. Upper Saddle River, NJ: Prentice hall.

Hoz-Rosales, B., Camacho Ballesta, J. A., \& Tamayo Torres, I. (2019). Effects of innovative entrepreneurship and the information society on social progress: an international analysis. Entrepreneurship and Sustainability Issues, 7(2), 782-813. http://doi.org/10.9770/jesi.2019.7.2(1)

Hu, L. T., \& Bentler, P. M. (1999). Cutoff criteria for fit indexes in covariance structure analysis: Conventional criteria versus new alternatives. Structural equation modeling: a multidisciplinary journal, 6(1), 1-55. https://doi.org/10.1080/10705519909540118

Keat, O. Y., Selvarajah, C., \& Meyer, D. (2011). Inclination towards entrepreneurship among university students: An empirical study of Malaysian university students. International Journal of Business and Social Science, 2(4), 206-220. Retrieved April 14, 2020, from http://www.ijbssnet.com/journals/Vol._2_No._4\%3B_March_2011/24.pdf

Kolvereid, L., \& Isaksen, E. (2006). New business start-up and subsequent entry into self-employment. Journal of Business Venturing, 21(6), 866-885. https://doi.org/10.1016/j.jbusvent.2005.06.008

Kourilsky, M. L., \& Walstad, W. B. (1998). Entrepreneurship and female youth: knowledge, attitude, gender differences, and educational practices. Journal of Business Venturing, 13(1), 77-88. https://doi.org/10.1016/S0883-9026(97)00032-3 


\section{ENTREPRENEURSHIP AND SUSTAINABILITY ISSUES}

ISSN 2345-0282 (online) http://jssidoi.org/jesi/

2020 Volume 8 Number 2 (December)

http://doi.org/10.9770/jesi.2020.8.2(27)

Make your research more visible, join the Twitter account of ENTREPRENEURSHIP AND SUSTAINABILITY ISSUES: @Entrepr69728810

Laviolette, E. M., Lefebvre, M. R., \& Brunel, O. (2012). The impact of story bound entrepreneurial role models on self-efficacy and entrepreneurial intention. International Journal of Entrepreneurial Behavior \& Research, 18(6), 720-742. https://doi.org/10.1108/13552551211268148.

Lee, L., \& Wong, P. K. (2003). Attitude towards entrepreneurship education and new venture creation. Journal of Enterprising Culture, 11(4), 339-357. https://doi.org/10.1142/S0218495803000111

Liñán, F., \& Chen, Y. W. (2009). Development and cross-cultural application of a specific instrument to measure entrepreneurial intentions. Entrepreneurship Theory and Practice, 33(3), 593-617. https://doi.org/10.1111/j.1540-6520.2009.00318.x

Lüthje, C., \& Franke, N. (2003). The 'making'of an entrepreneur: testing a model of entrepreneurial intent among engineering students at MIT. R\&D Management, 33(2), 135-147. https://doi.org/10.1111/1467-9310.00288

Maresch, D., Harms, R., Kailer, N., \& Wimmer-Wurm, B. (2016). The impact of entrepreneurship education on the entrepreneurial intention of students in science and engineering versus business studies university programs. Technological Forecasting and Social Change, 104, 172-179. https://doi.org/10.1016/j.techfore.2015.11.006

Moriano, J. A., Gorgievski, M., Laguna, M., Stephan, U., \& Zarafshani, K. (2012). A cross-cultural approach to understanding entrepreneurial intention. Journal of Career Development, 39(2), 162-185. https://doi.org/10.1177\%2F0894845310384481

Ogunleye, A. J., \& Osagu, J. C. (2014). Self-efficacy, tolerance for ambiguity and need for achievement as predictors of entrepreneurial orientation among entrepreneurs in Ekiti state, Nigeria. European Journal of Business and Management, 6(17), 240-250. Retrieved April 14, 2020, from https://www.iiste.org/Journals/index.php/EJBM/article/view/13634/13860

Ozaralli, N., \& Rivenburgh, N. K. (2016). Entrepreneurial intention: antecedents to entrepreneurial behavior in the USA and Turkey. Journal of Global Entrepreneurship Research, 6(1), 1-32. https://doi.org/10.1186/s40497-016-0047-x

Patricia, P., \& Silangen, C. (2016). The effect of entrepreneurship education on entrepreneurial intention in Indonesia. DeReMa (Development Research of Management): Jurnal Manajemen, 11(1), 67-86. http://dx.doi.org/10.19166/derema.v11i1.184

Peng, Z., Lu, G., \& Kang, H. (2013). Entrepreneurial intentions and its influencing factors: A survey of the university students in Xi'an China. Creative Education, 3(8), 95-100. https://doi.org/10.4236/ce.2012.38B021.

Purwana, D., \& Suhud, U. (2017). Entrepreneurship Education and Taking / Receiving \& Giving (TRG) Motivationson Entrepreneurial Intention: Do Vocational School Students Need an Entrepreneurial Motivator? International Journal of Applied Business and Economic Research, 15(22), 349-363. https://doi.org/10.5861/ijrsm.2015.1004

Rauch, A., \& Hulsink, W. (2015). Putting entrepreneurship education where the intention to act lies: An investigation into the impact of entrepreneurship education on entrepreneurial behavior. Academy of Management Learning \& Education, 14(2), 187-204. Retrieved April 14, 2020, from https://www.effectuation.org/wp-content/uploads/2017/06/Putting-Entrepreneurship-Educations-where-the-Intention-toAct-Lies-1.pdf

Rosmiati, R., Junias, D. T. S., \& Munawar, M. (2015). Sikap, motivasi, dan minat berwirausaha mahasiswa. Jurnal Manajemen dan Kewirausahaan, 17(1), 21-30. https://doi.org/10.9744/jmk.17.1.21-30

Samydevan, V., Piaralal, S., Othman, A. K., \& Osman, Z. (2015). Impact of psychological traits, entrepreneurial education and culture in determining entrepreneurial intention among pre-university students in Malaysia. American Journal of Economics, 5(2), 163-167. https://doi.org/10.5923/c.economics.201501.19

Sánchez, J. C. (2013). The impact of an entrepreneurship education program on entrepreneurial competencies and intention. Journal of small business management, 51(3), 447-465. https://doi.org/10.1111/jsbm.12025.

Saptono, A., \& Wibowo, A. (2018). Do learning environment and self-efficacy impact on student's entrepreneurial attitude?. International Journal of Entrepreneurship, 22(4), 1-11. Retrieved April 14, 2020, from https://www.abacademies.org/articles/Do-learning-environmentself-efficacy-impact-on-studes-entrepreneurial-attitude-1939-4675-22-4-220.pdf 


\section{ENTREPRENEURSHIP AND SUSTAINABILITY ISSUES}

ISSN 2345-0282 (online) http://jssidoi.org/jesi/

2020 Volume 8 Number 2 (December)

http://doi.org/10.9770/jesi.2020.8.2(27)

Make your research more visible, join the Twitter account of ENTREPRENEURSHIP AND SUSTAINABILITY ISSUES: @Entrepr69728810

Saptono, A., Purwana, D., Wibowo, A., Wibowo, S. F., Mukhtar, S., Yanto, H., ... Kusumajanto, D. D. (2019). Assessing the university students' entrepreneurial intention: Entrepreneurial education and creativity. Humanities and Social Sciences Reviews, 7(1), 505-514. https://doi.org/10.18510/hssr.2019.7158

Schermelleh-Engel, K., Moosbrugger, H., \& Müller, H. (2003). Evaluating the fit of structural equation models: Tests of significance and descriptive goodness-of-fit measures. Methods of Psychological Research Online, 8(2), 23-74. Retrieved April 14, 2020, from http://www.stats.ox.ac.uk/ snijders/mpr_Schermelleh.pdf

Shapero, A., \& Sokol, L. (1982). The social dimensions of entrepreneurship. Encyclopedia of entrepreneurship, 72-90. Retrieved April 14, 2020, from https://papers.ssrn.com/sol3/papers.cfm?abstract $\mathrm{id}=1497759$

Souitaris, V., Zerbinati, S., \& Al-Laham, A. (2007). Do entrepreneurship programmes raise entrepreneurial intention of science and engineering students? The effect of learning, inspiration and resources. Journal of Business venturing, 22(4), 566-591. https://doi.org/10.1016/j.jbusvent.2006.05.002

Tabachnick, B. G., Fidell, L. S., \& Ullman, J. B. (2007). Using multivariate statistics (Vol. 5). Boston, MA: Pearson.

Tong, X. F., Tong, D. Y. K., \& Loy, L. C. (2011). Factors influencing entrepreneurial intention among university students. International Journal of Social Sciences and Humanity Studies, 3(1), 487-496. Retrieved April 14, 2020, from http://www.sobiad.org/ejournals/journal_ijss/arhieves/2011_1/xue_fa_tong.pdf

Tung, D. T., Hung, N. T., Phuong, N. T. C., Loan, N. T. T., \& Chong, S. C. (2020). Enterprise development from students: The case of universities in Vietnam and the Philippines. International Journal of Management Education, 18(1), 100333. https://doi.org/10.1016/j.ijme.2019.100333

Turker, D., \& Selcuk, S. S. (2009). Which factors affect entrepreneurial intention of university students?. Journal of European Industrial Training, 33(2), 142-159. https://doi.org/10.1108/03090590910939049.

Turkina, E., \& Thai, M. T. T. (2013). Social capital, networks, trust and immigrant entrepreneurship: A cross-country analysis. Journal of Enterprising Communities: People and Places in the Global Economy, 7(2), 108-124 https://doi.org/10.1108/17506201311325779

Uddin, M. R., \& Bose, T. K. (2012). Determinants of entrepreneurial intention of business students in Bangladesh. International Journal of Business and Management, 7(24), 128-137. http://dx.doi.org/10.5539/ijbm.v7n24p128.

Utami, C. W. (2017). Attitude, subjective norms, perceived behaviour, entrepreneurship education and self-efficacy towards entrepreneurial intention university student in Indonesia. European Research Studies Journal, 20(24), 475-495. Retrieved April 14, 2020, from https://ideas.repec.org/a/ers/journl/vxxy2017i2ap475-495.html

Von Graevenitz, G., Harhoff, D., \& Weber, R. (2010). The effects of entrepreneurship education. Journal of Economic Behavior \& Organization, 76(1), 90-112. https://doi.org/10.1016/j.jebo.2010.02.015

Walter, S. G., \& Block, J. H. (2016). Outcomes of entrepreneurship education: An institutional perspective. Journal of Business Venturing, 31(2), 216-233. https://doi.org/10.1016/j.jbusvent.2015.10.003

Wang, C. K., \& Wong, P. K. (2004). Entrepreneurial interest of university students in Singapore. Technovation, 24(2), 163-172. https://doi.org/10.1016/S0166-4972(02)00016-0.

Wibowo, A., Saptono, A., \& Suparno. (2018). Does teachers' creativity impact on vocational students' entrepreneurial intention? Journal of Entrepreneurship Education, 21(3), 1-12. Retrieved April 14, 2020, from https://www.abacademies.org/articles/does-teachers39creativity-impact-on-vocational-students39-entrepreneurial-intention-7351.html

Wu, S., \& Wu, L. (2008). The impact of higher education on entrepreneurial intentions of university students in China. Journal of Small Business and Enterprise Development, 15(4), 752-774. https://doi.org/10.1108/14626000810917843

Yang, J. (2013). The theory of planned behavior and prediction of entrepreneurial intention among Chinese undergraduates. Social Behavior and Personality: An International Journal, 41(3), 367-376. https://doi.org/10.2224/sbp.2013.41.3.367 


\section{ENTREPRENEURSHIP AND SUSTAINABILITY ISSUES}

ISSN 2345-0282 (online) http://jssidoi.org/jesi/

2020 Volume 8 Number 2 (December)

http://doi.org/10.9770/jesi.2020.8.2(27)

Make your research more visible, join the Twitter account of ENTREPRENEURSHIP AND SUSTAINABILITY ISSUES: @Entrepr69728810

Zhang, Y., Duysters, G., \& Cloodt, M. (2014). The role of entrepreneurship education as a predictor of university students' entrepreneurial intention. International Entrepreneurship and Management Journal, 10(3), 623-641. https://doi.org/10.1007/s11365-012-0246-Z

Zhao, H., Seibert, S. E., \& Hills, G. E. (2005). The mediating role of self-efficacy in the development of entrepreneurial intentions. Journal of applied psychology, 90(6), 1265-1272. https://doi.org/10.1037/0021-9010.90.6.1265

\section{Acknowledgements}

This research was supported by Faculty of Economics, Universitas Negeri Malang, Indonesia

Djoko Dwi KUSUMOJANTO Djoko Dwi Kusumojanto is associate professor of entrepreneurship at Faculty of Economics Universitas Negeri Malang, Indonesia. He obtained his Ph.D in economic education from Universitas Negeri Malang. His concerned in entrepreneurship and entrepreneurship education. He has over 20 years of teaching experience in Faculty of Economics Universitas Negeri Malang. He has taught courses related to entrepreneurship, management, and educational. Research interests: entrepreneurship education; entrepreneurship; management.

ORCID ID: http://orcid.org/0000-0002-9630-2921

Bagus Shandy NARMADITYA is lecturer at Faculty of Economics Universitas Negeri Malang, Indonesia. He obtained his master in economic education from Universitas Negeri Malang. His concerned as editor and reviewer in several social sciences journal and focused on economic welfare and economic education. He participated in various international conference such as in Japan, Thailand, Vietnam and Indonesia. He also enrolled in the GSE summer school of economics in Barcelona, Spain. Research interests: entrepreneurship, entrepreneurship education; entrepreneurship; economics; economics education.

ORCID ID: http://orcid.org/0000-0002-4019-8723

Agus WIBOWO is assistant professor of entrepreneurship at Faculty of Economics Universitas Negeri Jakarta, Indonesia. He is doctoral candidate in Economic Education, Universitas Negeri Malang. His concerned as editor and reviewer in several social sciences journal and focused on entrepreneurship, entrepreneurship education, and economic education. He has taught courses related to entrepreneurship, educational management, and educational. Research interests: entrepreneurship education; entrepreneurship; management.

ORCID ID: http://orcid.org/0000-0003-0051-1743

Copyright (C) 2020 by author(s) and VsI Entrepreneurship and Sustainability Center

This work is licensed under the Creative Commons Attribution International License (CC BY).

http://creativecommons.org/licenses/by/4.0/

(c) (i) Open Access 